\title{
In vitro Wound Healing Potential and Antimicrobial Activity of Clerodendrum Inerme Leave Extracts
}

\author{
Sueptrakool Wisessombat ${ }^{1}$, Malatee Tayeh ${ }^{1,2, *}$
}

\section{Sueptrakool Wisessombat', Malatee Tayeh ${ }^{1,2, *}$}

'School of Allied Health Sciences, Walailak University, Nakhon Si Thammarat 80160 , THAILAND.

${ }^{2}$ Food Technology and Innovation Center of Excellence, Walailak University, Nakhon Si

Thammarat 80160 , THAILAND.

\section{Correspondence}

\section{Malatee Tayeh}

School of Allied Health Sciences, Walailak University, Nakhon Si Thammarat, THAILAND.

Phone no.: +66-75-672602;

E-mail: malateetayeh@gmail.com; tmalatee@wu.ac.th

History

- Submission Date: 15-08-2021;

- Review completed: 22-08-2021

- Accepted Date: 27-08-2021.

DOI : 10.5530/pj.2021.13.196

Article Available online

http://www.phcogj.com/v13/i6

Copyright

(C) 2021 Phcogj.Com. This is an openaccess article distributed under the terms of the Creative Commons Attribution 4.0 International license.

\begin{abstract}
Background: Clerodendrum inerme is a medicinal plant which exhibited many pharmacological effects. However, wound healing property of this plant has not been investigated. Objective: The present study was designed to evaluate wound healing and antimicrobial activities of $C$. inerme leaves using the in vitro model with Human keratinocytes (HaCaT). Methods: Cytotoxicity and wound healing effects were determined by MTT and scratch wound healing assay. Antimicrobial activities against cutaneous flora and clinical isolates of bacteria were investigated by broth microdilution assay. Results: The results showed that the water extract of $C$. inerme leaves did not exhibit cytotoxic effects on HaCaT cells, while ethanol extracts at higher concentrations significantly decreased cell growth with an $\mathrm{IC}_{50}$ value of $386.8 \pm 87.1$ $\mu \mathrm{g} / \mathrm{mL}$. The water extract and the lowest concentration $(6.25 \mu \mathrm{g} / \mathrm{mL})$ of the ethanol extract significantly increased percentage of wound closure compared with the untreated group. The water and ethanol extracts of $C$. inerme displayed a broad spectrum of antibacterial activity, inhibiting growth of Staphylococcus aureus, Staphylococcus.epidermidis, Escherichia coli, and Pseudomonas aeruginosa. The water extract displayed remarkable activity against methicillin-resistant $S$. aureus with $\mathrm{MIC}$ and $\mathrm{MBC}$ values ranging from 0.39 to $1.56 \mu \mathrm{g} / \mathrm{mL}$. Notably, it provided stronger antibacterial activity than vancomycin and also showed antifungal activity against $C$. albicans. Conclusion: This study confirms the potential of $C$. inerme leaves for wound healing and antimicrobial therapy and supports the continued utilization of $C$. inerme leaves in traditional medicine. Further studies are needed to clarify the molecular mechanisms through which it exerts such biological effects.

Key words: Antimicrobial activity, Clerodendrum inerme, Keratinocytes, Scratch assay, Wound healing.
\end{abstract}

\section{INTRODUCTION}

Wound healing is a physiological process which regenerates and replaces injured cells and involves three different phases including inflammation, new tissue formation, and remodeling. ${ }^{1}$ In this process, keratinocytes and fibroblasts, growth factors, cytokines, and their receptors as well as matrix molecules are required. ${ }^{2}$ The critical step for the success of the wound closure is the proliferation and migration of fibroblasts and keratinocytes. Keratinocytes are an important cell component of the outermost layer of the skin. They multiply and migrate into the epidermis' top layers, where they are differentiated and altered as they progress through the cell layers to their final maturity state. ${ }^{3}$ The wound healing process is adversely affected by oxidants, inflammation, nutritional condition, medications, and hormones. Furthermore, the type and location of the wound, conditions such as diabetes, and microbial infections can modulate effective wound healing. ${ }^{4} \mathrm{An}$ infected wound is less likely to heal, thus prevention or cure of infections are required for effective wound healing. Plant compounds were widely reported as potential agents with antimicrobial activity and are preferred because of their general availability, absence of adverse effects, and efficacy in crude preparations. ${ }^{5}$

Clerodendrum inerme L. Gaertn is a mangrove plant that is broadly distributed along the beach forests in South-east Asia, Australia and Pacific islands. ${ }^{6}$ C. inerme is a medicinal plant used in the treatment of rheumatism, cough, scrofula, venereal infection, skin diseases, beri-beri, tumors and wound healing. ${ }^{7-9}$ The leaves of $C$. inerme are used in conjunction with other plant leaves for the treatment of fever, cough, skin rashes, chronic pyrexia and boils. ${ }^{10}$ C. inerme exhibits hepatoprotective, ${ }^{7}$ antiinflammatory, ${ }^{11}$ anti-bacterial, ${ }^{12-13}$ anti-oxidant ${ }^{14}$ and anticancer activities. ${ }^{15-17}$ However, thus far effects of $C$. inerme leave extracts on wound healing have not been reported. The present study aimed to evaluate the pharmacological effects of water and ethanol extracts of $C$. inerme leaves on wound healing.

\section{MATERIALS AND METHODS}

\section{Chemical reagents}

3-(4,5-Dimethylthiazol-2-yl)-2,5-diphenyl2H-tetrazolium bromide (MTT), trypan blue, dimethylsulfoxide (DMSO) were purchased from Sigma-Aldrich (St. Louis, MO, U.S.A). Phosphate buffered saline and fetal bovine serum (FBS) were purchased from Merck Millipore Corp (Darmstadt, Germany). Powdered Dulbecco's modified Eagle's medium (DMEM), penicillin-streptomycin and $0.25 \%$ trypsin-EDTA were purchased from Gibco ${ }^{\circ}$, (Grand Island, NY, USA).

\section{Collection of plant material and extracts preparation}

C. inerme leave parts were collected in the Pak-Poon Community, Nakhon Si Thammarat, Thailand, in May 2020. The voucher specimen was deposited at the herbarium in the Botanic Garden of Walailak University, Nakhon Si Thammarat, Thailand, under number 01521. Fresh leaves were washed under running tap water and then dried for 36 hours using

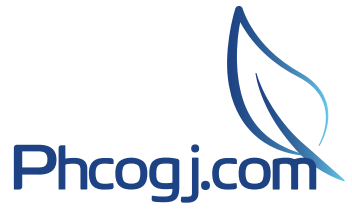

Cite this article: Wisessombat S, Tayeh M. In vitro Wound Healing Potential and Antimicrobial Activity of Clerodendrum Inerme Leave Extracts. Pharmacogn J. 2021;13(6):1542-1548. 
a hot air oven at $60{ }^{\circ} \mathrm{C}$. Dried leaves were crushed and subjected to extraction using the maceration process in distilled water and ethyl alcohol (95\%) for 7 days at room temperature. Extracts were collected and concentrated at $40{ }^{\circ} \mathrm{C}$ under reduced pressure using a rotary evaporator. The dried extracts were stored at $4{ }^{\circ} \mathrm{C}$ until further analysis.

\section{Cell culture}

Human keratinocytes (HaCaT) were provided by Professor Ramida Watanapokasin from Department of Biochemistry, Faculty of Medicine, Srinkharinwirot University, Thailand. HaCaT cells were grown in Dulbecco's modified Eagle's medium (DMEM), supplemented with $10 \%$ fetal bovine serum (FBS), $100 \mathrm{IU} / \mathrm{ml}$ penicillin, and $100 \mathrm{mg} / \mathrm{mL}$ streptomycin. Cultures were incubated in a humidified atmosphere with $5 \% \mathrm{CO}_{2}$ at $37^{\circ} \mathrm{C}$. Cultured cells were dispersed/distributed every $72 \mathrm{~h}$. The confluent culture was subcultured using $0.25 \%$ of trypsinEDTA.

\section{Cytotoxic assay}

An MTT test was used to determine the viability of HaCaT cells. Cells $\left(1 \times 10^{4}\right.$ cells/well $)$ were seeded in a 96-well plate in DMEM culture media (Gibco, Grand Island, NY, USA) supplemented with 10\% FBS and incubated for 24 hours at $37^{\circ} \mathrm{C}$ in a $5 \% \mathrm{CO}_{2}$ atmosphere. Water and ethanol extracts at various concentrations $(0-400 \mathrm{~g} / \mathrm{mL})$ were applied to cells for 24 hour. After treatment, a $0.5 \mathrm{mg} / \mathrm{mL}$ MTT solution was added to each well and incubated at $37^{\circ} \mathrm{C}$ in a humidified atmosphere witch $5 \% \mathrm{CO}_{2}$ for 2 hours. The culture medium was removed and cells were suspended in $100 \mu \mathrm{L}$ DMSO. Absorbance at $570 \mathrm{~nm}$ was determined by a Microplate spectrophotometer and the percentage of cell viability was calculated relative to the control. The $\mathrm{IC}_{50}$ value was calculated using the software GraphPad Prism 3.03 (GraphPad Software Inc, CA). Data were recorded for three independent experiments and are shown as mean \pm SEM.

\section{In Vitro wound healing scratch assay}

The scratch wound-healing assay was used with modifications as previously described. ${ }^{18}$ Briefly, HaCaT cells $\left(5 \times 10^{4}\right)$ were seeded into 12 -well cell culture plates and allowed to grow to $90 \%$ confluence as a monolayer. Cells were starved with serum-free medium for 24 hours. The monolayer was gently scratched with a sterile $200 \mu \mathrm{L}$ pipette tip. After scratching, the culture medium was removed, and cellular debris was removed by washing with PBS solution. Serum-free medium with non-cytotoxic concentrations of the extract of $C$. inerme leaves was added and incubated for 24 hours at $37{ }^{\circ} \mathrm{C}$ in a $5 \% \mathrm{CO}_{2}$ atmosphere. Cells without treatment and cells treated with allantoin (SigmaAldrich, Germany) $(50 \mu \mathrm{g} / \mathrm{mL})$ were used as negative and positive control, respectively. Images of the scratched areas were photographed at 0 and 24 hours post-treatment using an inverted microscope (Carl Zeiss Microscopy, NY, USA) and analyzed using NIH ImageJ software (Bethesda, Maryland, USA). Wound healing was estimated by the percentage of scratch closure at each dose point relative to the control. Three independent experiments were performed for each data point and the percentage of wound closure was calculated using the following formula:

$[($ Wound area t0 - Wound area t24)/Wound area t0] $\times 100$

\section{Bacterial strains and culture conditions}

Antimicrobial activity of water and ethanol extracts was tested against Gram-positive bacteria including Staphylococcus aureus ATCC25923, S. epidermidis ATCC12228 and methicillin-resistant S. aureus (MRSA) and Gram-negative bacteria including, Escherichia coli ATCC25922 and Pseudomonas aeruginosa ATCC27853, was tested by a modified broth microdilution method according to the Guidelines of the Clinical and Laboratory Standards Institute Guidelines. ${ }^{19}$ The bacteria were grown in trypticase soy medium (Merck, Germany) at $37^{\circ} \mathrm{C}$. Candida albicans was grown on Sabouraud dextrose agar (BD Difco, MD, USA). A single colony of bacteria was isolated by cross streaking on medium and incubated at $37^{\circ} \mathrm{C}$ for $18-20$ hours.

\section{Antimicrobial activities}

Minimum inhibitory concentration (MIC) was the lowest concentration of samples that did not result in bacterial growth. Water and ethanol extracts of $C$. inerme were dissolved in 10\% DMSO and two-fold dilutions were made. Microorganisms obtained from the overnight broth culture were suspended in Muller-Hinton broth (Merck KGaA, Darmstadt, Germany). The bacterial cells suspension was mixed with the diluted test agents in a microtiter plate (Thermo Fisher Scientific, MA, USA). The final concentration was $0.5 \times 10^{5} \mathrm{CFU} / \mathrm{mL}$. The final concentration of the extracts ranged from 0.39 to $100 \mu \mathrm{g} / \mathrm{mL}$ and microtiter plates were incubated at $37{ }^{\circ} \mathrm{C}$ for $18-20$ hours. The MIC was observed. Aliquots were plated onto Muller-Hinton agar plates and incubated at $37^{\circ} \mathrm{C}$ for $18-20$ hours. The minimum bactericidal concentration (MBC) was recorded as the lowest concentration of the extracts preventing bacterial growth completely.

\section{Time-kill assay}

Time-kill assay was used to study the killing activity of the water extract on MRSA at hourly intervals for 6 hours and 24 hours. The bacterial cells inoculum approximately $0.5 \times 10^{6} \mathrm{CFU} / \mathrm{mL}$ was added to MullerHinton broth (1:10), supplemented with water extract at concentrations of $0.5 \mathrm{MIC}, \mathrm{MIC}, 1 \mathrm{MIC}$, and $2 \mathrm{MIC}$ and incubated at $37^{\circ} \mathrm{C}$. Viable counts were performed by a drop plate method. The test was carried out in duplicate and results are shown as the mean of the log numbers of bacterial cells.

\section{Statistical analysis}

All data were subjected to statistical analysis using the SPSS 23.0 software package (IBM Software Inc, Chicago, IL, USA). Data are reported as mean \pm standard error of the mean $( \pm$ SEM) of three independent experiments. Statistical significance was analyzed by the one-way ANOVA test. Differences between treated group and untreated group were determined statistically significant at $p<0.05$.

\section{RESULTS}

\section{Cytotoxic effect of $C$. inerme leave extracts}

The cytotoxic effect of water and ethanol extracts from $C$. inerme leaves on HaCaT cells were evaluated by a viability assay using MTT. As shown in Figure 1, there was no cytotoxic effect and an increase in cell growth was observed at extract concentrations of 6.25 to $400 \mu \mathrm{g} / \mathrm{mL}$ for $24 \mathrm{~h}$. The $\mathrm{IC}_{50}$ value was determined to $>200 \mu \mathrm{g} / \mathrm{mL}$. The ethanol extract did not exhibit a cytotoxic effect at lower concentrations However, a cytotoxic effect was observed at a concentration of $200 \mu \mathrm{g} / \mathrm{mL}$ and an $\mathrm{IC}_{50}$ value of $386.8 \pm 87.1 \mu \mathrm{g} / \mathrm{mL}$. We found that the ethanol extract at concentrations from 6.25 to $25 \mu \mathrm{g} / \mathrm{mL}$ increased cell viability and 50 $100 \mu \mathrm{g} / \mathrm{mL}$ of ethanol extract produced a cell viability of more than $90 \%$ The data obtained in this study indicate better viability of $\mathrm{HaCaT}$ cells at lower concentrations.

\section{Effect of $C$. inerme leave extracts on cell migration}

The effect of water and ethanol extracts of $C$. inerme leaves on cell migration was determined by a scratch wound healing assay. Cells with and without treatment by $C$. inerme leave extracts were allowed to migrate into the denuded area for $24 \mathrm{~h}$ at $37^{\circ} \mathrm{C}$ and wound closure was determined by using a microscope with Image J software. Allantoin was used as a positive control drug at a concentration of $50 \mu \mathrm{g} / \mathrm{mL}$. The water extract of $C$. inerme leaves $(6.25-100 \mu \mathrm{g} / \mathrm{mL})$ significantly 


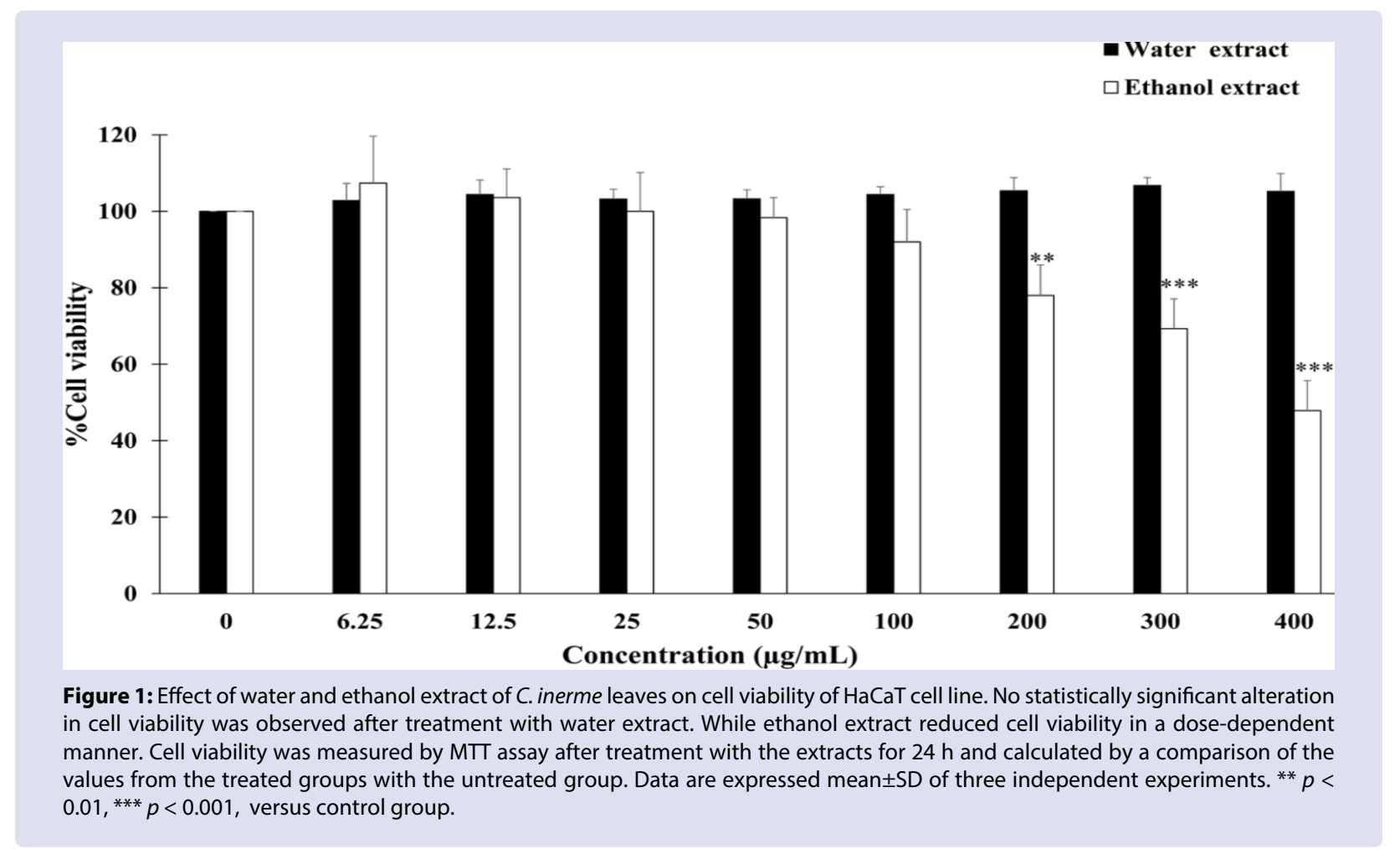

enhanced the wound closure rate when compared to the untreated group after $24 \mathrm{~h}$ (Figure 2A). Cells treated with water extracts at 6.25 , $12.5,25$ and $50 \mu \mathrm{g} / \mathrm{mL}$ showed a dramatic enhancement in wound closure. The water extract at $100 \mu \mathrm{g} / \mathrm{mL}$ also showed a potent wound healing effect on HaCaT by $54.1 \pm 9.9 \%(p<0.01)$ when compared to the control group where only $30.6 \pm 7.8 \%$ were observed (Figure $2 \mathrm{~B}$ ).

In contrast, the ethanol extract of $C$. inerme leaves displayed a significant effect on wound closure when compared to the control group $(p<$ $0.05)$. However, at higher concentrations it did not affect the wound closure rate of $\mathrm{HaCaT}$ cells (Figure 3). The results indicate that water and ethanol extracts at low concentrations are suitable like traditional remedies to improve wound healing whereby the water extract had a marked effect on cell proliferation and migration.

\section{Antimicrobial activities of $C$. inerme leave extracts}

Antimicrobial activity of water and ethanol extracts of $C$. inerme on both reference and clinical isolated strains of bacteria are shown in Table 1 . The water extract demonstrated antimicrobial activity against S. aureus, S. epidermidis and C. albicans with MIC values of $0.78,1.56$, and $6.25 \mu \mathrm{g} / \mathrm{mL}$, respectively. The ethanol extract displayed activity with the MIC values of $1.56,3.13$ and $12.50 \mu \mathrm{g} / \mathrm{mL}$ against $S$. aureus, $S$. epidermidis, and C. albicans, respectively.

Interestingly, the water extract of $C$. inerme displayed remarkable activity against MRSA with MIC and MBC values ranging from 0.39 to $1.56 \mu \mathrm{g} / \mathrm{mL}$ and thus provided stronger antibacterial activity than vancomycin, which displayed 3 times higher MIC values and 3 times higher MBC values Table 1. It also had antifungal activity against a clinical isolate of $C$. albicans. MIC of the water and ethanol extracts tested with E. coli and P. aeruginosa were higher than $100 \mathrm{mg} / \mathrm{mL}$, the highest concentration tested.

\section{Time-kill assay}

Methicillin-resistant strains of $S$. aureus were incubated with the water extract at amounts of $0.5,1$ and 2 MIC and samples were analyzed at time intervals for bactericidal activity. At all test concentrations, the water extract showed a significant bactericidal activity on all clinical isolated MRSA. Bactericidal activity was defined as a decrease of $\geq 3$ $\log$ units in CFU/mL. From the results, 99\% killing was observed at 6,5 , and $4 \mathrm{~h}$ when treated with $0.5 \mathrm{MIC}$, MIC, and $2 \mathrm{MIC}$, respectively. Moreover, the most significant bactericidal activity ( $\geq 99.9 \%$ killing) was observed at 24,6 , and $5 \mathrm{~h}$ at $0.5 \mathrm{MIC}$, MIC, and $2 \mathrm{MIC}$, respectively.

\section{DISCUSSION}

Plants and their extracts have been used for the treatment of wounds since ancient times. Treatments using plant-extracts are widespread, available, easily accessible and lack side effects. Often their use is based on tradition without any scientific evidence of efficacy and with little knowledge about active compounds or their modes of action. In this study we first demonstrate that water and ethanol extracts of $C$. inerme leaves are conducive to an improvement of wound repair. We have performed a cytotoxicity test first to determine a range of crude extract concentrations that have no cytotoxic effects on HaCaT cells. We found that extract concentrations ranging from 6.25 to $400 \mu \mathrm{g} /$ $\mathrm{mL}$ of water extracts had no significant effect on cell viability and even enhanced the cell viability of $\mathrm{HaCaT}$ cells. Ethanol extracts at lower concentrations $(6.25-25 \mu \mathrm{g} / \mathrm{mL})$ increased cell viability whereas at higher concentrations cell growth was significantly inhibited. Water and ethanol extracts were selected at their non-toxic concentrations to determine the effect on a possible stimulation of HaCaT cell migration. We found that both water and ethanol extract are suitable as traditional remedies to improve wound healing. The $C$. inerme water extract exhibited a better-wound healing capacity than the ethanol extract. Several phytochemical constituents have been isolated from $C$. inerme leaves such as alkaloids, steroids, tannins, phenolic compounds, flavonoids, and terpenoids which possess various properties such as antioxidation and antimicrobial activities, promote wound healing and skin regeneration. ${ }^{4,20-23}$ A previous study showed that extracts of leaves, stem bark and roots of $K$. africana and S. hispidus contain alkaloids, saponins, tannins, flavonoids, carbohydrates, and sapogenetic glycosides 


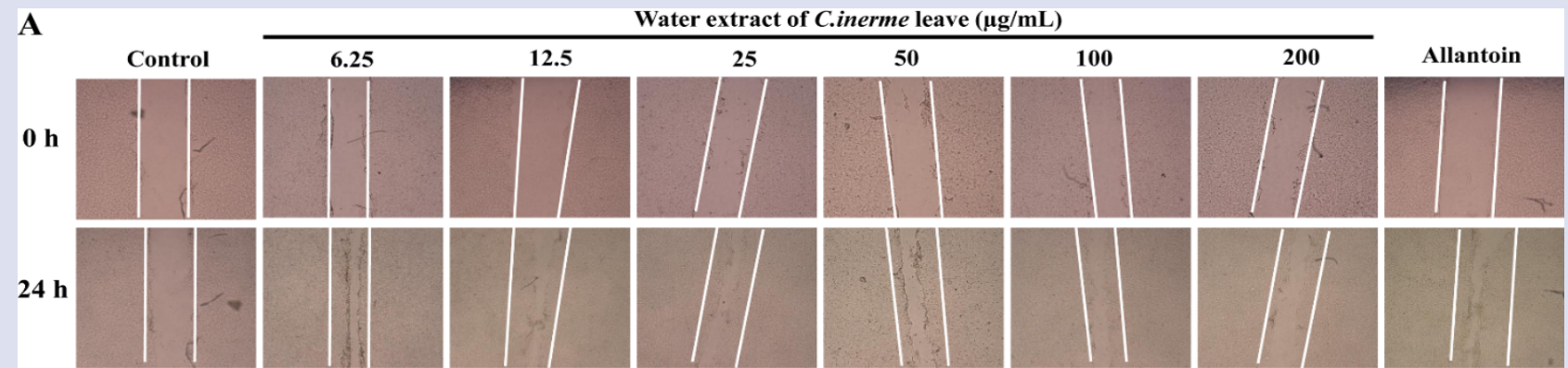

B

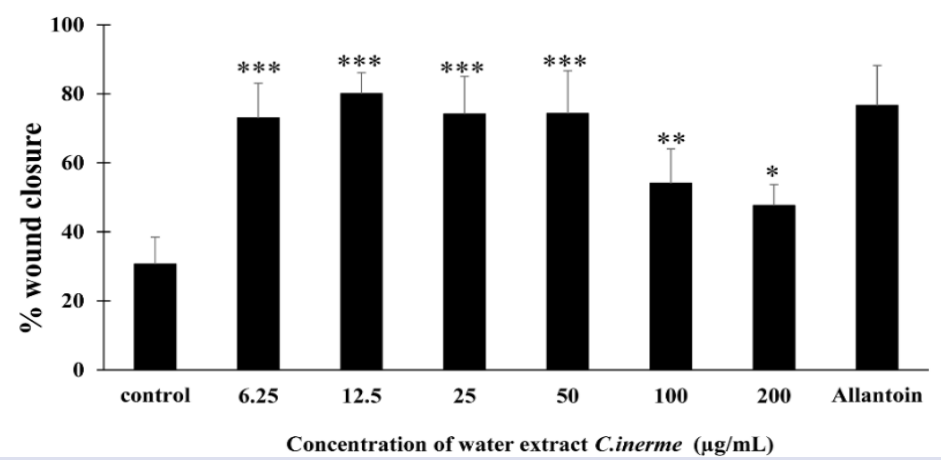

Figure 2: Effect of water extract of $C$. inerme leaves on cell migration was determined by scratch wound healing assay. (A) Digital images captured at $5 x$ magnification using an inverted microscope at 0 and 24 after treatment. (B) The wound closure rate in percentage of HaCaT cell after treatment with water extract of $C$. inerme leaves for $24 \mathrm{~h}$. Quantitative analysis of the migration rate was analyzed with the use of ImageJ software. Data are expressed as mean \pm standard deviation from three individual experiments. ${ }^{*} p<0.05$, ${ }^{* *} p<0.01$, ${ }^{* * *} p<0.001$, versus control group.

A
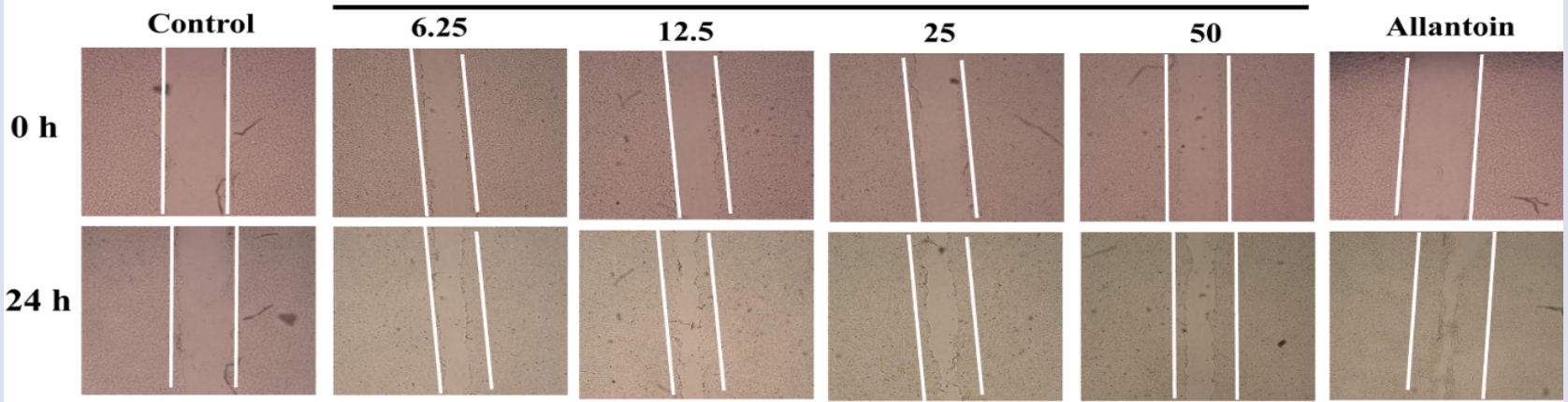

$\mathbf{B}$

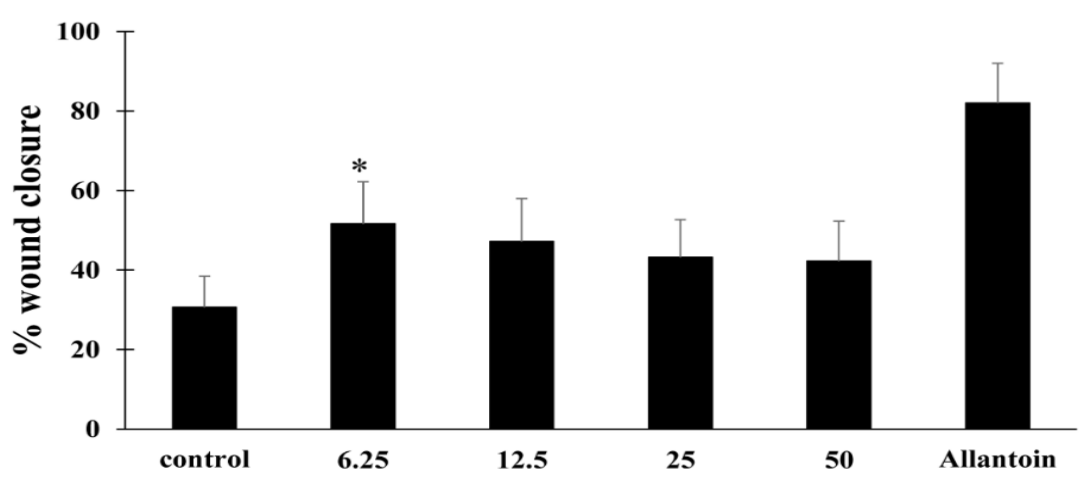

Concentration of ethanol extract $(\mu \mathrm{g} / \mathrm{mL})$

Figure 3: Effect of ethanol extract of $C$. inerme leaves on cell migration was determined by scratch wound healing assay. (A) Digital images captured at $5 x$ magnification using an inverted microscope at 0 and 24 after treatment. (B) The wound closure rate in percentage of HaCaT cell after treatment with water extract of $C$. inerme leaves for $24 \mathrm{~h}$. Quantitative analysis of the migration rate was analyzed with the use of ImageJ software. Data are expressed as mean \pm standard deviation from three individual experiments. ${ }^{*} p<0.05$ versus control group. 
Table 1: The minimum inhibitory concentration (MIC) and minimal bactericidal concentration (MBC) of C. inerme leave extracts against skin microorganisms.

\begin{tabular}{|c|c|c|c|}
\hline Microorganisms & \multicolumn{2}{|c|}{$\mathrm{MIC} / \mathrm{MBC}(\mu \mathrm{g} / \mathrm{mL})$} & Antibiotics $(\mu \mathrm{g} / \mathrm{mL})$ \\
\hline Staphylococcus aureus ATCC25923 & $0.78 / 1.56$ & $1.56 / 1.56$ & $0.62 / 1.25^{\mathrm{a}}$ \\
\hline Methicillin-resistant Staphylococcus aureus 2 & $0.39 / 0.78$ & $0.78 / 1.56$ & $1.25 / 125^{\mathrm{a}}$ \\
\hline Methicillin-resistant Staphylococcus aureus 3 & $0.39 / 0.78$ & $0.78 / 1.56$ & $1.25 / 125^{\mathrm{a}}$ \\
\hline Staphylococcus epidermidis ATCC12228 & $1.56 / 1.56$ & $3.13 / 3.13$ & $0.78 / 1.56^{\mathrm{a}}$ \\
\hline Candida albicans (clinical isolated) & $6.25 / 6.25$ & $12.50 / 12.50$ & $0.25 / 0.25^{\mathrm{b}}$ \\
\hline Escherichia coli ATCC25922 & $>100 />100$ & $>100 />100$ & $0.50 / 0.50^{c}$ \\
\hline Pseudomonas aeruginosa ATCC27853 & $>100 />100$ & $>100 />100$ & $1.50 / 3.00^{c}$ \\
\hline
\end{tabular}

${ }^{\mathrm{a}}=$ vancomycin $^{\mathrm{b}}=\operatorname{amphotericin}^{\mathrm{B}}$, and ${ }^{\mathrm{c}}=$ gentamicin

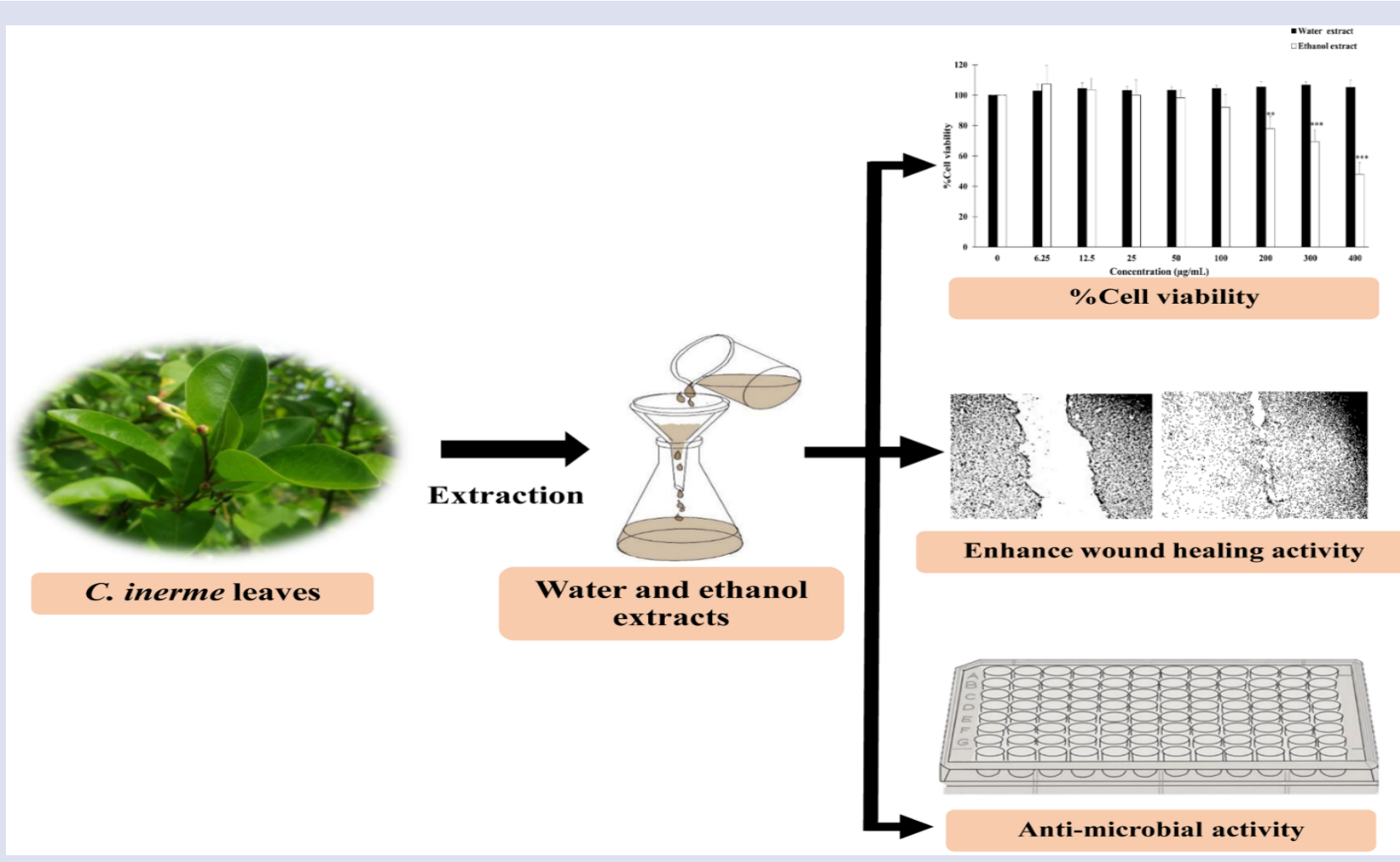

Figure 4: Schematic representation of $C$. inerme leaves on wound healing potential and antimicrobial activity.

which exhibit antimicrobial, antioxidant and enhanced wound healing properties..$^{24}$ Likewise, Agyare et al. reported the presence of tannins, flavonoids, alkaloids, and glycosides in J. flava and L. welwitschii extracts and their antimicrobial and wound healing properties. ${ }^{25}$ Some studies have reported that high concentrations of flavonoid contents of $A$. bracteolata inhibit cell proliferation of human fibroblast and HaCaT cell. ${ }^{26,27}$ Flavonoids contained in a hydro-ethanol extract of $C$. officinalis stimulate potentiated wound healing by stimulating in vitro and in vivo proliferation of dermal fibroblasts. ${ }^{28}$ Recently the potential of other species such as Aloe muth-muth and Digitaria ciliaris in wound healing of the immortalized human keratinocyte (HaCaT) cell line was reported. ${ }^{29,30}$

We have also evaluated in vitro antimicrobial activity of the water and ethanol extracts of $C$. inerme leaves. The water extract had demonstrated substantial activity against methicillin-resistant $S$. aureus and S. Aureus. The activity of the water extract with MIC values ranged from 0.39 to $0.78 \mu \mathrm{g} / \mathrm{mL}$, respectively. The MBC was 2 - to 4 -fold greater than the
MIC, suggesting that the water extract is highly bactericidal against these pathogenic species. Moreover, extracts of $C$. inerme demonstrated antifungal activity against $C$. albicans, whereas it no significant activity against 2 tested strains of Gram-negative bacteria.

Water was the most effective solvent for extracting antibacterial constituents from $C$. inerme which indicates that the antibacterial constituents of $C$. inerme are highly polar. The susceptibility pattern we have observed correlates well with those obtained for other extracts of medicinal plant. ${ }^{31}$ Gram-negative bacteria are generally less susceptible to antibacterial agents than Gram-positive organisms due to the low permeability of their cell walls. ${ }^{32}$

\section{CONCLUSION}

The results presented in our study indicate that $C$. inerme leaves can exhibit prominent antimicrobial and wound healing activity (Figure 4). The findings further support traditional applications of $C$. inerme leaves 
for the cure of infections and as wound healing agent. Future studies are needed to identify and isolate major components responsible for wound healing. The effects of $C$. inerme extracts on signaling pathways underlying proliferation and migration of keratinocytes warrant further investigation as well as the development of hydrogel bandages containing $C$. inerme leaf extracts.

\section{ACKNOWLEDGEMENTS}

This work was supported by the Institute of Research institute for Health Sciences, Walailak University "Research Grant No. WU-IRG-63-003". We would like to thank Professor Ramida Watanapokasin from Department of Biochemistry, Faculty of Medicine, Srinkharinwirot University, Thailand for providing $\mathrm{HaCaT}$ cell lines. We are thankful to Dr. Gerd Katzenmeier, School of Allied Health Sciences, Walailak University, for critical reading of the manuscript.

\section{CONFLICTS OF INTEREST}

The authors declare that they have no competing interests.

\section{REFERENCES}

1. Saqallah FG, Hamed WM, Talib WH. In vivo evaluation of Antirrhinum majus' wound healing activity. Sci Pharm. 2018;86:45.

2. Kuonen R, Weissenstein U, Urech K, Kunz M, Hostanska K, Estko M, Heusser $P$, Baumgartner S. Effects of lipophilic extract of viscum album L. and oleanolic acid on migratory activity of NIH/3T3 fibroblasts and on HaCaT keratinocytes. Evid. Based Complement Alternat. Med. 2013;718105:1-7.

3. Kim J, Shin YK, Kim KY. Promotion of keratinocyte proliferation by Tracheloside through ERK 1/2 stimulation. Evid Based Complement Alternat Med. 2018;4580627:1-5.

4. Ali-Seyed M, Siddiqua A. Calotropis - A multi-potential plant to humankind: Special focus on its wound healing efficacy. Biocatal. Agric. Biotechnol. 2020;28:101725.

5. Murugan D, Kalachaveedu M, Subbarayan R, Jenifer P, Suresh RR. Aristolochia bracteolata enhances wound healing in vitro through anti-inflammatory and proliferative effect on human dermal fibroblasts and keratinocytes. Pharmacogn. J. 2017;9:129-36.

6. Gopal N, Sengottuvelu S. Hepatoprotective activity of Clerodendrum inerme against $\mathrm{CCl}_{4}$ induced hepatic injury in rats. Fitoterapia. 2008;79:24-26.

7. Muthu C, Ayyanar M, Raja N, Ignacimuthu S. Medicinal plants used by traditional healers in Kancheepuram district of Tamil Nadu, India. J. Ethnobiol. Ethnomed. 2006;2:43.

8. Kanchanapoom T, Kasai R, Chumsri P, Hiraga $Y$, Yamasaki K. Megastigmane and iridoid glucosides from Clerodendrum inerme. Phytochemistry. 2001;58:333-36.

9. Al-Snafi AE. Chemical constituents and pharmacological effects of Clerodendrum inerme- A Review. SMU Medical Journal. 2016;3:129-52.

10. Kalyani SS, Holihosur RSN. Toxic effect of crude aqueous leaf extracts of Clerodendron inerme, on the total haemocyte count of sixth instar larva of Helicoverpa armigera (H). IJIRST. 2015;1:22124.

11. Yankanchi SR, Koli SA. Anti-inflammatory and analgesic activity of mature leaves methanol extract of Clerodendrum inerme $\mathrm{L}$. (Gaertn). J. Pharm. Sci. Res. 2010;2:782-85.

12. Wutithamawech $W$, Tantirungkij M, Liangsakul P. Antibacterial potential of some Thai medicinal plants. Int. J. Pharma. Bio. Sci. 2014;5:412-21.

13. Chahal J, Sarin R, Malwal M. Efficacy of Clerodendrum inerme L. (Garden Quinine) against some human pathogenic strains. Int. J. Pharma. Bio. Sci. 2010;1:219-23.

14. Khan SA, Rasool N, Riaz M, Nadeem R, Rashid U, Rizwan K, et al. Evaluation of antioxidant and cytotoxicity studies of Clerodendrum inerme. Asian J. Chem. 2013;25:7457-62.
15. Renju GL, Manoharan S, Balakrishnan S, Senthil N. Chemopreventive and antilipidperoxidative potential of Clerodendron inerme $(\mathrm{L})$ Gaertn in 7, 12-dimethylbenz(a)anthracene induced skin carcinogenesis in Swiss albino mice. Pak. J. Biol. Sci. 2007;10:1465-70.

16. Manoharan S, Kavitha K, Senthil N, Renju GL. Evaluation of anticarcinogenic effects of Clerodendron inerme on 7, 12-dimethylbenz(a) anthracene-induced hamster buccal pouch carcinogenesis. Singapore Med. J. 2006;47:1038-43.

17. Tayeh M, Hiransai $\mathrm{P}$, Kommen $\mathrm{H}$, Watanapokasin R. Antimigration and anti-invasion abilities of methanolic leaves extract of Clerodendrum inerme on lung cancer cells. Pharmacogn. J. 2020;12:1024-31.

18. Sonkar K, Pachauri M, Kumar A, Shukla A, Patel M, Jagannadham M. Heme-peroxidase from medicinal plant Artocarpus lakoocha: Purification, characterization and wound healing studies. Biocatal. Agric. Biotechnol. 2015;4:180-90.

19. Clinical and Laboratory Standards Institute. Methods for dilution antimicrobial susceptibility tests for bacteria that grow aerobically approved standard-10 $10^{\text {th }}$ ed. M07-A11. Clinical and Laboratory Standards Institute, Wayne, PA. 2018.

20. Krishnadhas L. Isolation and identification of flavonoid fractions from the leaves of Volkameria inermis and its in-vitro cytotoxic study. Int. J. Pharm. Clin. 2017;8:1648-53.

21. Paulraj SMS, Rajkumar JR, Nadar MM. Phytochemicals as a potential source for anti-microbial, anti-oxidant and wound healing a review. MOJ. bioorg. org. chem. 2018;2:61-70.

22. Bhushan B, Sardana S, Bansal G. Phytochemical and pharmacognostical studies of leaves of Clerodendrum inerme. Der Pharm. Lett. 2015;7:157-61.

23. Shami MA, Saadedin MKS, Hasan FS. Study of antibacterial and antioxidant activities of alkaloids fraction from Clerodendron inerme leaves. Ann Trop Med PH. 2020;23:1-8.

24. Girija DM, Kalachaveedu M, Subbarayan $R$, Jenifer $P$, Rao SR Aristolochia bracteolata enhances wound healing in vitro through anti-inflammatory and proliferative effect on human dermal fibroblasts and keratinocytes. Pharmacogn. J. 2017;9:129-36.

25. Agyare C, Bempah SB, Boakye Y, Ayande PG, Adarkwa-Yiadom $\mathrm{M}$, Mensah KB. Evaluation of antimicrobial and wound healing potential of Justicia flava and Lannea we/witschii. Evid. Based Complementary Altern. Med. 2013;632927:1-10.

26. Agyare C, Dwobeng AS, Agyepong N, Boakye YD, Mensah KB, Ayande PG, Adarkwa-Yiadom M. Antimicrobial, antioxidant, and wound healing properties of Kigelia africana (Lam.) Beneth. and Strophanthus hispidus DC. Adv. Pharmacol. Pharm. Sci. 2013;692613:1-10.

27. Park $\mathrm{CH}$, Min SY, Yu HW, Kim K, Kim S, Lee HJ, Kim JH, Park YJ. Effects of apigenin on RBL-2H3, RAW264.7, and HaCaT cells: Antiallergic, anti-inflammatory, and skin-protective activities. Int. J. Mol. Sci. 2020;21:4620.

28. Dinda M, Mazumdar S, Das S, Ganguly D; Dasgupta UB, Dutta A, Jana $\mathrm{K}$, Karmakar P. The Water fraction of Calendula officinalis hydroethanol extract stimulates in vitro and in vivo proliferation of dermal fibroblasts in wound healing. Phytother Res. 2016;30:1696-707.

29. Fouche M, Willers C, Hamman S, Malherbe C, Steenekamp J. Wound healing effects of Aloe muth-muth: In vitro investigations using immortalized human keratinocytes (HaCaT). Biology. 2020:9:350.

30. Park SM, Won KJ, Hwang DI, Kim DY, Kim HB, Li Y, Lee HM Potential beneficial effects of Digitaria ciliaris flower absolute on the wound healing-linked activities of fibroblasts and keratinocytes. Planta Med. 2020;86:348-55.

31. Devequi-Nunes D, Machado BAS, Barreto GdA, Rebouças Silva J, da Silva DF, et al. Chemical characterization and biological activity of six different extracts of propolis through conventional methods and supercritical extraction. PLOS ONE. 2018;13:e0207676.

32. Delcour AH. Outer membrane permeability and antibiotic resistance. Biochim. Biophys. Acta. 2009;1794:808-16. 


\section{GRAPHICAL ABSTRACT}

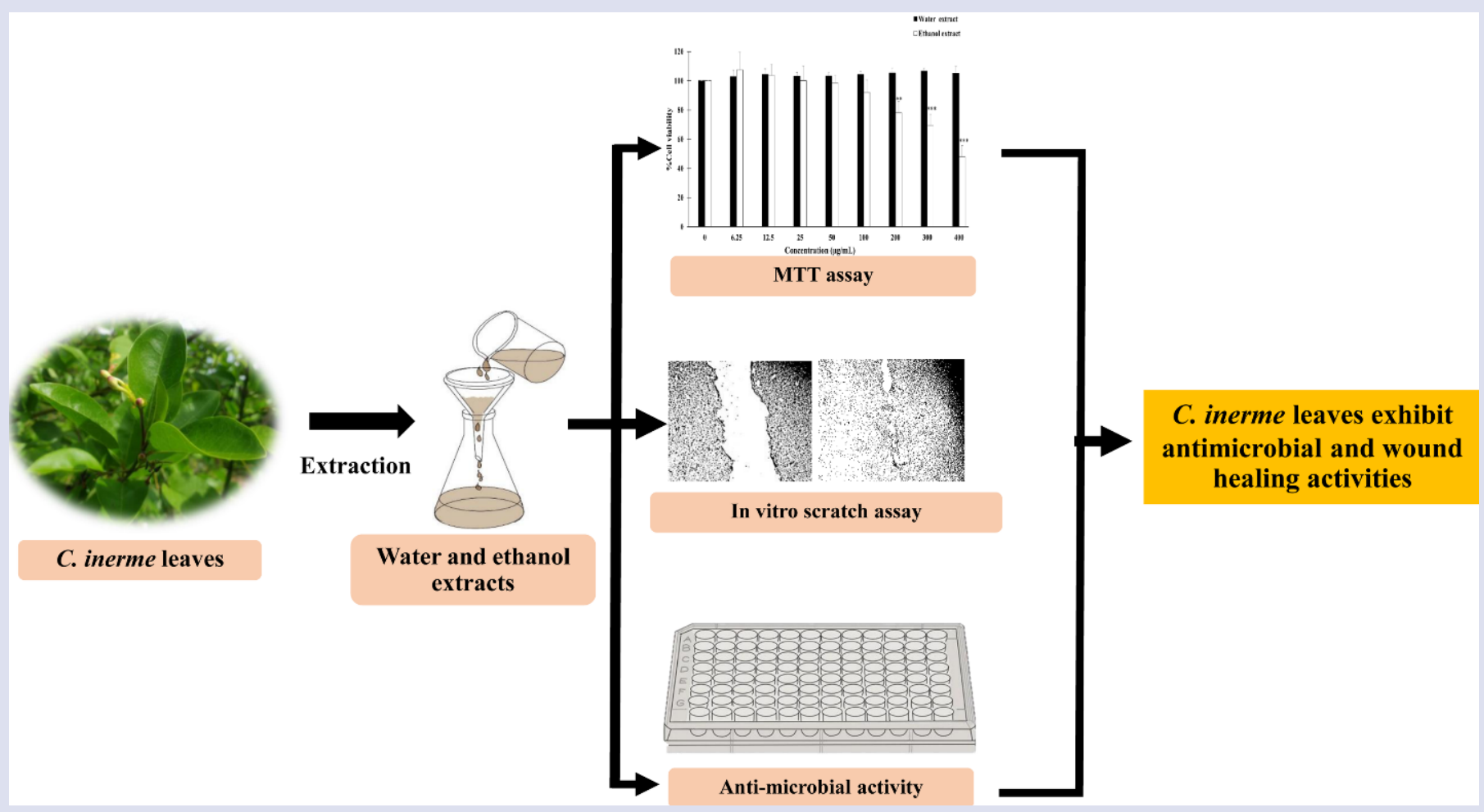

\section{ABOUT AUTHORS}
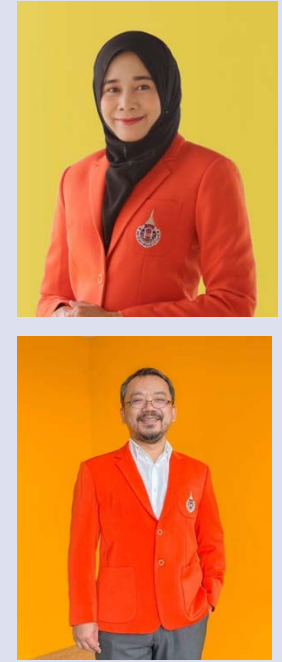

Asst. Prof. Dr. Malatee Tayeh is currently working as lecturer in Medical Technology at School of Allied Health Sciences, Walailak University, Thailand. Her current research interests in natural product, cancer biology, cancer metastasis, hemostasis, wound healing and cell signaling transduction.

Asst. Prof. Dr. Sueptrakool Wisessombat is a lecturer and researcher at Walailak University in the School of Allied Health Sciences. His research focuses on development of a selective media for fastidious bacterial culture; Helicobacter pylori, Campylobacter jejuni, and also mold; dermatophytes.

Cite this article: Wisessombat S, Tayeh M. In vitro Wound Healing Potential and Antimicrobial Activity of Clerodendrum Inerme Leave Extracts. Pharmacogn J. 2021;13(6): 1542-1548. 